\title{
Preferensi Petani terhadap Pembiayaan Syariah di Kabupaten Jember
}

\author{
Farmers'Preference on Islamic Financing in Jember Regency
}

\author{
Herman Cahyo Diartho ${ }^{1 *}$, Rohmad Kurniawan ${ }^{1}$ \& Zaenuri $^{1}$ \\ ${ }^{1}$ Program Studi Ekonomi Pembangunan, Fakultas Ekonomi dan Bisnis, Universitas Jember, \\ Jalan Kalimantan Nomor 37, Kampus Tegalboto, Jember, Jawa Timur, 68121, Indonesia; 'Penulis \\ korespondensi.e-mail: @ hermancahyodiartho@yahoo.com \\ (Diterima: 7 Juli 2018; Disetujui: 20 Juni 2019)
}

\begin{abstract}
Islamic financing system continues to evolve, which can be observed from the increase in the number of financial institutions that employ Islamic financing models from bank level to cooperative level. Islamic financial institutions were initially related to large industrial sector but then began to enter the field of agriculture, so it is necessary to conduct research on farmers' preference on Islamic economic financing. This research has three objectives: to understand the significance influence of easiness factor, knowledge factor, and trust factor on farmers' preference on Islamic financing. The method of SEM (Structural Equation Modeling) was used as a tool in order to solve problems in this research through calculation using of AMOS 21 application. Results of the research shows that there is only one factor that has significant effect on Islamic financing, which is the trust factor with a coefficient of 0.090. Meanwhile the knowledge factor and easiness factor has no significant effect.
\end{abstract}

Keywords: farmer preference, Islamic financing, Structural Equation Modeling

\begin{abstract}
ABSTRAK
Sistem pembiayaan syariah terus berkembang ditandai dengan meningkatnya jumlah lembaga keuangan yang menggunakan model pembiayaan syariah dari tingkat bank hingga koperasi. Lembaga keuangan Islam pada awalnya hanya pada sektor industri besar, namun semakin lama mulai memasuki bidang pertanian, sehingga diperlukan penelitian tentang preferensi petani terhadap pembiayaan ekonomi Islam. Penelitian ini memiliki tiga tujuan, yakni untuk mengetahui apakah faktor-faktor kemudahan, pengetahuan, dan kepercayaan mempengaruhi preferensi petani terhadap pembiayaan syariah. Metode SEM (Structural Equation Modeling) merupakan alat yang digunakan dalam rangka membantu menyelesaikan permasalahan pada penelitian ini dengan perhitungan melalui aplikasi AMOS 21. Hasil penelitian menunjukkan bahwa hanya ada satu faktor yang berpengaruh signifikan terhadap pembiayaan syariah yaitu faktor kepercayaan dengan koefisien sebesar 0.090. Sementara itu, faktor pengetahuan dan faktor kemudahan tidak berpengaruh signifikan.
\end{abstract}

Kata kunci: preferensi petani, sistem pembiayaan syariah, Structural Equation Modeling

\section{PENDAHULUAN}

Indonesia merupakan negara

berkedaulatan yang membentang luas dari Sabang sampai Merauke dengan ribuan pulau sehingga banyak dari masyarakat Indonesia bekerja sebagai petani. Menurut Diartho (2018), sektor ekonomi termasuk sektor pertanian yang memiliki peran dalam perkembangan ekonomi daerah dan nasional. Pekerjaan penduduk 
Indonesia sebagai petani menyebabkan salah satu subsektor yaitu tanaman pangan menjadi kunci utama yang berperan dalam menunjang peningkatan pendapatan setiap daerah yang akan berakibat positif bagi perekonomian nasional. Menurut Diartho \& Muktianto (2018), pertanian di Indonesia memberikan kontribusi besar bagi perekonomian daerah dalam bentuk penyerapan tenaga kerja dan pemasok bahan pangan. Sektor pertanian merupakan sumber bahan pangan yang memiliki peran besar sehingga tidak bisa diganti dengan sektor lain. Menurut Laili \& Diartho (2018), tanaman pangan berpotensi dalam meningkatkan perekonomian daerah karena dapat dikembangkan dan diproduksi untuk menghasilkan produk unggulan yang siap dijual ke luar daerah. Tanaman yang dapat tumbuh dan berkembang serta dapat diolah kembali untuk dijadikan sumber makanan dan sumber ekonomi bagi manusia adalah tanaman pangan. Terdapat banyak jenis tanaman pangan, antara lain; padi, jagung, gandum, kedelai, wortel, dan kentang. Menurut Diartho (2018), hasil produksi pertanian harus didorong agar mampu menghasilkan bahan olahan. Jumlah penduduk di Indonesia yang banyak mengakibatkan kebutuhan pangan sangat tinggi. Salah satu kebutuhan pangan tersebut adalah padi. Jumlah permintaan terhadap padi yang tinggi menyebabkan padi menjadi komoditi berkontribusi besar bagi perekonomian Indonesia.

Padi (Oryza sativa) merupakan sumber karbohidrat utama bagi mayoritas penduduk di dunia, yang sudah dikenal dan dibudidayakan oleh petani di seluruh wilayah nusantara. Tanaman padi banyak diusahakan oleh petani di Indonesia dan juga mayoritas masyarakat Indonesia menjadikan hasil dari budidaya tanaman padi, yaitu beras sebagai makanan pokok. Menurut Wiratama et al. (2018), Jawa Timur merupakan daerah dengan sumber daya alam yang banyak salah satunya adalah sektor pertanian, sehingga tidak salah jika dikatakan Jawa Timur menjadi salah satu daerah dengan penyumbang penerimaan daerah terbesar.

Tabel 1 Luas panen, produksi, dan produktivitas padi sawah dan padi ladang Jawa Timur 2015

\begin{tabular}{lllll}
\hline No & Kabupaten & $\begin{array}{l}\text { Luas Panen } \\
\text { (Ha) }\end{array}$ & $\begin{array}{l}\text { Produktivitas } \\
\text { (Kw/Ha) }\end{array}$ & Produksi (Ton) \\
\hline 1 & Kabupaten Jember & 163,263 & 61.16 & 998,559 \\
2 & Kabupaten Lamongan & 137,980 & 64.39 & 888,412 \\
3 & Kabupaten Banyuwangi & 130,765 & 65.27 & 853,530 \\
4 & Kabupaten Bojonegoro & 137,159 & 57.83 & 793,172 \\
5 & Kabupaten Ngawi & 122,870 & 61.31 & 753,285 \\
\hline
\end{tabular}

Sumber: Provinsi Jawa Timur dalam angka (2016)

Tabel 1 menunjukkan bahwa Kabupaten Jember memiliki produksi padi tertinggi di antara keempat daerah lain di Jawa Timur. Total produksi padi di Kabupaten Jember mencapai 998,559 ton dari luas area panen 163,263 Ha.
Sementara itu di wilayah Kabupaten Jember sendiri, Kecamatan Wuluhan merupakan wilayah kecamatan di Kabupaten Jember yang memiliki produktivitas tanaman padi cukup tinggi [Tabel 2].

Tabel 2 Data luas lahan, produktivitas, dan produksi padi kecamatan di Kabupaten Jember 2015

\begin{tabular}{lllll}
\hline No & Kecamatan & Luas Panen (ha) & Produktivitas (kw/ha) & Produksi (kw) \\
\hline 1. & Wuluhan & 4,740 & 69.38 & 328,900 \\
2. & Puger & 5,675 & 68.94 & 391,200 \\
3. & Umbulsari & 3,158 & 68.91 & 217,620 \\
4. & Ambulu & 3,804 & 67.47 & 256,670 \\
5. & Kencong & 5,869 & 65.96 & 387,120 \\
\hline
\end{tabular}

Sumber: Kabupaten Jember dalam angka (2016)

Tabel 2 memperlihatkan bahwa Kecamatan Wuluhan memiliki produktivitas tanaman padi yang paling tinggi di Kabupaten Jember. Selain itu, luas area panen padi di
Kecamatan Wuluhan mempunyai perbandingan yang sama sehingga dapat disimpulkan bahwa luasan area sawah di Kecamatan Wuluhan dapat dimanfaatkan secara maksimal oleh para petani 
untuk memproduksi padi. Tetapi hal tersebut tidak didukung dengan sumbangan hasil dari subsektor tanaman pangan di Produk Domestik Regional Bruto (PDRB) Kabupaten Jember.

Tabel 3 Produk Domestik Regional Bruto atas dasar harga konstan sektor pertanian Kabupaten Jember 2012-2015 (Miliar Rupiah)

\begin{tabular}{|c|c|c|c|c|c|}
\hline \multirow{2}{*}{ No } & \multirow{2}{*}{ Sektor Pertnian } & \multicolumn{4}{|c|}{ Tahun } \\
\hline & & 2012 & 2013 & 2014 & 2015 \\
\hline 1 & Tanaman Pangan & 3144.41 & 3322.25 & 3393.70 & 3543.70 \\
\hline 2 & Hortikultura & 1108.35 & 1132.20 & 1156.55 & 1211.88 \\
\hline 3 & Perkebunan & 4128.33 & 4243.53 & 4434.86 & 4681.54 \\
\hline 4 & Peternakan & 2003.83 & 2105.81 & 2169.63 & 2173.69 \\
\hline 5 & Kehutanan & 379.73 & 374.79 & 396.15 & 405.65 \\
\hline 6 & Perikanan & 770.01 & 795.73 & 842.31 & 895.62 \\
\hline
\end{tabular}

Sumber: Kabupaten Jember dalam angka (2016)

Tabel 3 menunjukkan bahwa kontribusi subsektor tanaman pangan terhadap PDRB ternyata masih kalah dengan subsektor perkebunan dan menunjukkan bahwa pembangunan terhadap subsektor tanaman pangan masih belum optimal sehingga kontribusi terhadap PDRB masih belum optimal. Salah satu masalah kompleks dari subsektor tanaman pangan yang menjadi beban bagi petani adalah masalah penyediaan modal.

Salah satu penyebab sulitnya lembaga pembiayaan masuk pada sektor pertanian adalah karena karakteristik dari sektor pertanian sendiri yang rentan terhadap resiko kegagalan. Selain itu, pembiayaan yang ditawarkan pada sistem pembiayaan konvensional berbasis bunga menjadi faktor yang memberatkan bagi usaha tani.

Melihat realita yang ada, maka perlulah membenahi segala permasalahan pada sektor pertanian. Realita ini menunjukkan bahwa petani sangat jauh dari kata sejahtera, padahal petani merupakan mayoritas penduduk miskin di daerah perdesaan yang membutuhkan perhatian dan pemihakkan dari pemerintah maupun para pakar ekonomi pertanian. Salah satu permasalahan utama yang dihadapi petani adalah permodalan. Permodalan menjadi sangat penting karena untuk memulai usaha pertanian seberapa besar atau kecil yang dilakukan pasti memerlukan modal. Maka ketersedian modal selanjutnya menjadi kebutuhan yang sangat penting bagi petani.

Dengan melihat permasalahan di atas, penelitian ini ingin melihat sejauh mana pembiayaan syariah yang diterapkan pada sektor pertanian dengan menggunakan tiga macam variabel untuk mengukur preferensi pembiayaan syariah, yaitu faktor pengetahuan, faktor kemudahan, dan faktor kepercayaan.

Faktor pengetahuan merupakan perubahan perilaku individu dalam menggunakan informasi produk sehingga dapat memutuskan pilihan yang akan dipilih pada saat proses pembelian produk (Teguh et al., 2000). Faktor kemudahan merupakan persepsi seseorang terhadap penggunaan teknologi apakah memudahkan atau menyulitkan suatu kegiatan atau usaha yang dilakukan. Faktor kepercayaan didefinisikan sebagai harapan untuk menyakinkan seseorang terhadap mitranya yang akan memberikan apa yang ia mau (Dimyati, 2009).

Konsep preferensi adalah kemampuan individu dalam menyikapi keperluan terhadap barang dan jasa yang diinginkan dengan memberi penilaian (Marwan \& Asri, 1990). Proses pengambilan keputusan dan kegiatan fisik setiap orang merupakan dua elemen dalam konsep preferensi. Karakterisitik yang mempengaruhi preferensi terdiri dari budaya, pribadi, ekonomi, psikologi, dan pembeli.

Berdasarkan latar belakang di atas, maka disusunlah suatu pertanyaan penelitian yang menjadi perumusan masalah sebagai berikut: (a) Apakah faktor pengetahuan mempengaruhi preferensi petani terhadap pembiayaan syariah?; (b) Apakah faktor kemudahan mempengaruhi prefrensi petani terhadap pembiayaan syariah?; dan (c) Apakah faktor kepercayaan mempengaruhi preferensi petani terhadap pembiayaan syariah?. 


\section{METODOLOGI}

\section{Jenis dan Sumber Data}

Penelitian ini menggunakan metode deskriptif kuantitatif dengan data primer yang didapatkan dari petani. Objek penelitian yang digunakan adalah petani pada Kecamatan Wuluhan di Kabupaten Jember. Penentuan lokasi penelitian ini dilakukan dengan teknik purposive sampling.

\section{Metode Analisis Data}

Untuk menjawab permasalahan pertama, kedua, dan ketiga penelitian ini digunakan SEM (Structural Equation Modeling) sebagai metode analisis datanya. SEM merupakan salah satu metode analisis multivariat dalam ilmu sosial. Analisis multivariat merupakan metode serempak (Sholihin et al., 2013). Penelitian ini menggunakan SEM berdasarkan beberapa alasan sebagai berikut:

1. Model yang diuji berbentuk kausalitas

2. Analisis kausalitas memiliki kelemahan dikarenakan hanya mampu mengidentifikasikan satu hubungan pada satu waktu yang seperti regresi berganda, analisis faktor, analisis diskriminan dan lainlain.

3. Metode SEM dapat menganalisis beberapa beberapa hubungan dari beberapa variabel laten dalam satu waktu.

Kuesioner yang sudah terkumpul dianalisis menggunakan AMOS 21 yang memiliki permasalahan terstruktur dan digunakan untuk menguji model hipotesis. Hal ini disebabkan karena adanya kemampuan untuk memperkirakan koefisien yang diketahui dari persamaan linier struktural, mengakomodasi model sebagai variabel laten, mengakomodasi kesalahan pengukuran pada variabel dependen dan independen, mengakomodasi peringatan timbal balik simultan dan saling ketergantungan.

Menurut Ferdinand dalam Dimyati, (2009) SEM memiliki beberapa tahapan antara lain: (a) mengumpulkan semua informasi dari pengkajian literatur, (b) laporan ilmiah, hasil penelitian sebelumnya, (c) dan laporan yang ada kaitannya dengan penelitian untuk merumuskan teori-teori kausalitas.

\section{Hipotesis}

Berdasarkan perumusan masalah, maka hipotesis yang akan diteliti adalah sebagai berikut:

1. Faktor pengetahuan berpengaruh signifikan terhadap minat pembiayaan syariah.

2. Faktor kemudahan berpengaruh signifikan terhadap minat pembiayaan syariah.

3. Faktor kepercayaan berpengaruh signifikan terhadap minat pembiayaan syariah.

\section{HASIL DAN PEMBAHASAN}

\section{Hasil Analisis Data}

1. Uji Normalitas

Uji normalitas digunakan untuk mengetahui data berdistribusi normal atau tidak dan juga perlu dilakukan baik untuk normalitas terhadap data univariat maupun normalitas mutivariat dimana beberapa variabel yang digunakan sekaligus dalam analisis akhir sehingga mengetahui berdistribusi normal atau tidak.

Tabel 4 Hasil pengujian normalitas

\begin{tabular}{lllll}
\hline Variabel & Min & Max & Kurtosis & c.r. \\
\hline Y13 & 3.000 & 5.000 & -.683 & -1.395 \\
Y12 & 2.000 & 5.000 & -.650 & -1.326 \\
Y11 & 2.000 & 5.000 & -.493 & -1.006 \\
X31 & 1.000 & 5.000 & .135 & .276 \\
X32 & 1.000 & 5.000 & -.510 & $-1,041$ \\
X33 & 2.000 & 5.000 & -.424 & -.866 \\
X34 & 2.000 & 5.000 & -.795 & -1.623 \\
X21 & 1.000 & 5.000 & -.966 & -1.972 \\
X22 & 1.000 & 5.000 & -.432 & -.883 \\
\hline
\end{tabular}


Tabel 4 Lanjutan

\begin{tabular}{lllll}
\hline Variabel & Min & Max & Kurtosis & c.r. \\
\hline X23 & 1.000 & 5.000 & -.818 & -1.670 \\
X24 & 1.000 & 5.000 & -.801 & -1.634 \\
X11 & 1.000 & 5.000 & -.572 & -1.167 \\
X12 & 1.000 & 5.000 & -.408 & -.833 \\
X13 & 1.000 & 5.000 & -.022 & -.044 \\
X14 & 1.000 & 5.000 & .239 & .489 \\
X15 & 1.000 & 5.000 & -.072 & -.146 \\
Multivariat & & & 7,818 & 1.629 \\
\hline
\end{tabular}

Sumber: Analisis dengan program AMOS 21

Nilai statistik $\mathrm{z}$ dapat digunakan dalam pengujian asumsi normalitas dengan melihat $\mathrm{CR}$. Karakter data termasuk dalam distribusi normal secara univarat ataupun multivariat apabila apabila tingkat signifikan 5\% dan CR (-1.96 s $\mathrm{CR} \leq 1.96$ ) (Ghozali, 2005).

Hasil pengujian menunjukkan data termasuk multivariat normal dikarenakan memberikan nilai CR 1.629 diantara $-1.96 \leq \mathrm{CR}$ $\leq 1.96(\alpha=0.05)$ dan data termasuk univariat dikarenakan memberikan nilai CR di antara -1.96 $\leq \mathrm{CR} \leq 1.96$.

\section{Uji Validitas}

Valid tidaknya pertanyaan untuk mengukur dimensi atau variabel laten merupakan tujuan dari dilakukannya uji validitas. Loading factor merupakan indikator untuk mengukur suatu dimensi dengan syarat lebih besar 0.5. Tujuan lainnya adalah reliable dengan standar hasil konsisten pada waktu dan kondisi berbeda. Composite (Construction) reliability dengan Cut Off Value minimal sebesar 0.70 digunakan untuk menghitung reabilitas (Ghozali, 2005).

Tabel 5 Pengujian validitas dan reabilitas konstruksi

\begin{tabular}{llllll}
\hline Variabel & Item & Loading Faktor & $\begin{array}{c}\text { Cut } \\
\text { Off }\end{array}$ & Keterangan & $\begin{array}{l}\text { Construct } \\
\text { Reliability }\end{array}$ \\
\hline Pengetahuan & X11 & 0.835 & 0.5 & Valid & 0.90092 \\
& X12 & 0.783 & 0.5 & Valid & \\
X13 & 0.808 & 0.5 & Valid & \\
X14 & 0.854 & 0.5 & Valid & \\
Kemudahan & X15 & 0.817 & 0.5 & Valid & \multirow{2}{*}{0.890199} \\
& X21 & 0.946 & 0.5 & Valid & \\
Kepercayaan & X22 & 0.767 & 0.5 & Valid & \\
& X23 & 0.810 & 0.5 & Valid & \\
& X24 & 0.840 & 0.5 & Valid & \\
& X31 & 0.815 & 0.5 & Valid & 0.890949 \\
Xembiayaan Syariah & X32 & 0.858 & 0.5 & Valid & \\
& X34 & 0.720 & 0.5 & Valid & \\
& Y1 & 0.876 & 0.5 & Valid & \\
& Y2 & 0.789 & 0.5 & Valid & 0.598 \\
\hline
\end{tabular}

Sumber: Analisis dengan program AMOS 21

Tabel 5 menunjukkan bahwa hasil perhitungan loading faktor dengan nilai diatas 0.5 sehingga semua indikator data penelitian dapat dikatakan valid. Di sisi lain, CR semua variabel menunjukkan hasil yang melebihi nilai 0.70 . Dengan demikian berdasarkan CR, semua item yang mengukur variabel pengetahuan, kemudahan dan kepercayaan dinyatakan reliable.

\section{Hasil diagram Structural Equation Equation} Modeling (SEM). Data yang telah valid dan reliabel, multivariat normat dan tidak terjadi data outlier akan dilakukan uji kesesuaian model dan signifikansi kausalitas yang memperoleh adanya hubungan antar variabel laten [Gambar 4]. 


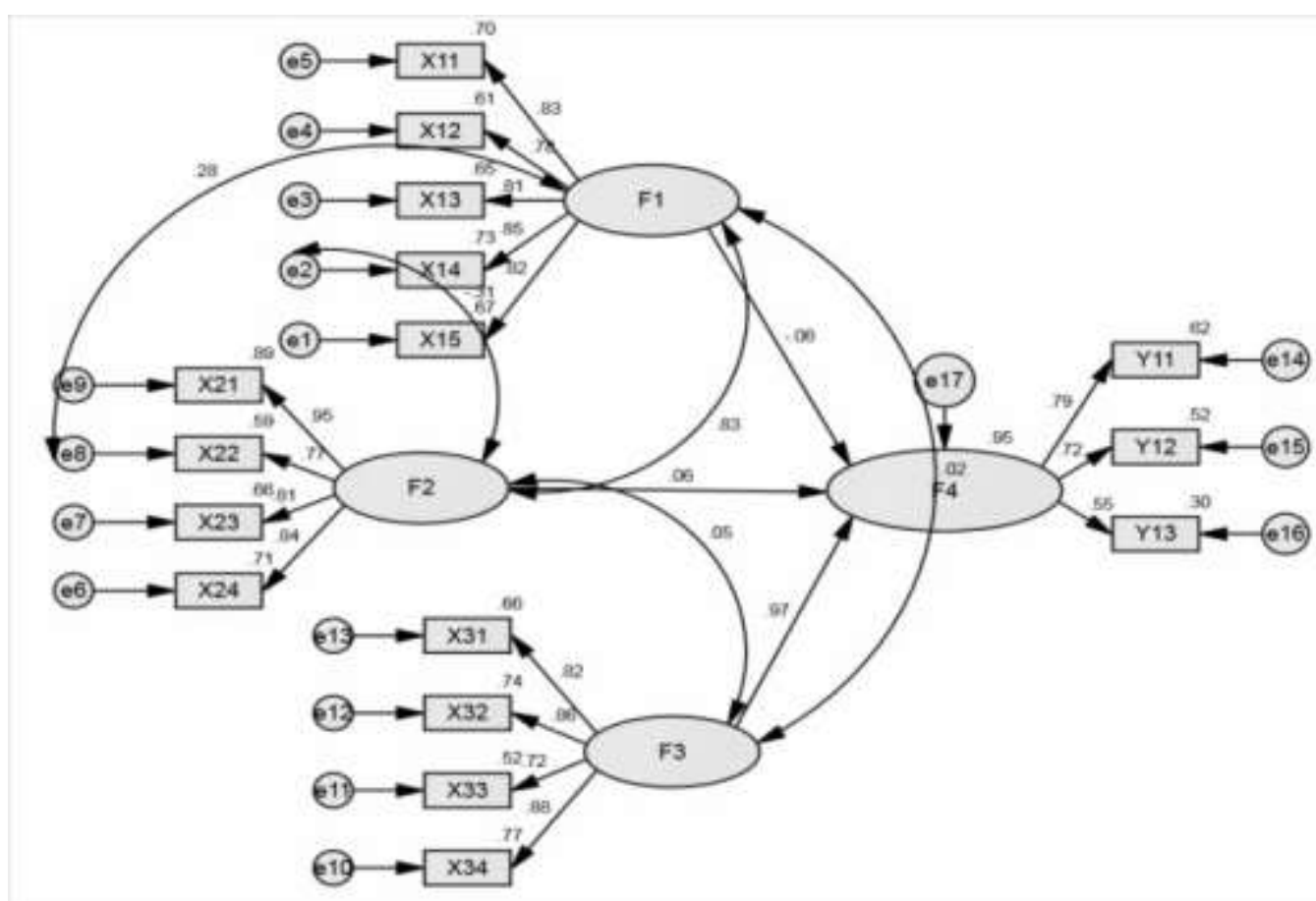

Gambar 4 Hasil diagram Structural Equation Modeling (SEM)

Sumber: Analisis dengan program AMOS 21

Keterangan:

F1 : Variabel Pengetahuan

F2 : Variabel Kemudahan

\section{Kontribusi Indikator Pengukur Variabel Laten}

Besarnya muatan atau kontribusi masingmasing indikator dalam mengukur variabel laten dapat diketahui melalui loading factor masingmasing indikator. Besarnya loading factor dapat dilihat melalui penjelasan berikut:

a. Kontribusi Indikator Pengukur Variabel Pengetahuan

Tabel 6 Kontribusi indikator pengukur variabel

\begin{tabular}{lll}
\multicolumn{1}{c}{ pengetahuan } & & \\
\hline Variabel & Indikator & Estimate \\
\hline & $\mathrm{X}_{1.1}$ & 0.835 \\
Pengetahuan & $\mathrm{X}_{1.2}$ & 0.783 \\
& $\mathrm{X}_{1.3}$ & 0.808 \\
& $\mathrm{X}_{1.4}$ & 0.854 \\
& $\mathrm{X}_{1.5}$ & 0.817 \\
\hline
\end{tabular}

Sumber: Analisis dengan program AMOS 21

Tabel 6 menunjukkan bahwa $X_{1.1}, X_{1.2}$, $\mathrm{X}_{1.3}, \mathrm{X}_{1.4}$ dan $\mathrm{X}_{1.5}$ masing-masing berkontribusi pada pengukuran keragaman variabel pengetahuan sebesar $83.5 \%, 78.3 \%, 80.8 \%$, $85.4 \%$ dan $81.7 \%$. Kontribusi masing-masing indikator tersebut diukur melalui nilai loading yang masing-masing bernilai $0.835,0.783,0.808$,
F3 : Variabel Kepercayaan

F4 : Variabel Pembiayaan Syariah
0.854 dan 0.817. Indikator X.1.4 merupakan indikator yang paling dominan dari pada indikator lain dikarenakan memiliki nilai loading dan kontribusi tertinggi sebesar 0.854 dan kontribusi sebesar $85.4 \%$.

b. Kontribusi Indikator Pengukur Variabel Kemudahan

Tabel 7 Kontribusi indikator pengukur variabel kemudahan

\begin{tabular}{lll}
\hline Variabel & Indikator & Estimate \\
\hline \multirow{4}{*}{ Kemudahan } & $\mathrm{X}_{2.1}$ & 0.946 \\
& $\mathrm{X}_{2.2}$ & 0.767 \\
& $\mathrm{X}_{2.3}$ & 0.810 \\
& $\mathrm{X}_{2.4}$ & 0.840 \\
\hline
\end{tabular}

Sumber: Analisis dengan program AMOS 21

Tabel 7 menunjukkan bahwa $\mathrm{X}_{2.1}$ merupakan indikator yang paling dominan dengan nilai loading sebesar 0.946 yang berarti berkontribusi sebesar 94.6\%. Ketiga indikator lainnya, yaitu $\mathrm{X}_{2.2}, \mathrm{X}_{2.3}, \mathrm{X}_{.2 .4}$ masing-masing berkontribusi pada pengukuran keragaman variabel kemudahan sebesar $76.7 \%, 81 \%, 84 \%$. Kontribusi masing-masing indikator tersebut 
diukur melalui nilai loading yang masing-masing bernilai $0.767 ; 0.810 ; 0.840$.

c. Kontribusi Indikator Pengukur Variabel Kepercayaan

Tabel 8 Kontribusi indikator pengukur variabel kepercayaan

\begin{tabular}{lll}
\hline Variabel & Indikator & Estimate \\
\hline \multirow{4}{*}{ Kepercayaan } & $\mathrm{X}_{3.1}$ & 0.815 \\
& $\mathrm{X}_{3.2}$ & 0.858 \\
& $\mathrm{X}_{3.3}$ & 0.720 \\
& $\mathrm{X}_{3.4}$ & 0.876 \\
\hline
\end{tabular}

Sumber: Analisis dengan program AMOS 21

Tabel 8 menunjukkan bahwa $\quad$ X.3.4 berkontribusi sebesar $87.6 \%$ dengan nilai loading sebesar 0.876 yang berarti indikator tersebut paling dominan dari pada indikator lain. Ketiga indikator lain, yaitu $\mathrm{X}_{3.1}, \mathrm{X}_{3.2}, \mathrm{X}_{3.3}$ masing-masing berkontribusi pada pengukuran keragaman variabel kepercayaan sebesar $81.5 \%, 85.8 \%$, $72 \%$. Kontribusi masing-masing indikator tersebut diukur melalui nilai loading yang masing-masing bernilai $0.815 ; 0.858 ; 0.720$.

d. Kontribusi Indikator Pengukur Variabel Pembiayaan Syariah

Tabel 9 Kontribusi indikator pengukur variabel pembiayaan syariah

\begin{tabular}{lll}
\hline Variabel & Indikator & Estimate \\
\hline \multirow{4}{*}{ Pembiayaan Syariah } & $\mathrm{Y}_{1.1}$ & 0.789 \\
& $\mathrm{Y}_{1.2}$ & 0.724 \\
& $\mathrm{Y}_{1.3}$ & 0.546 \\
\hline
\end{tabular}

Sumber: Analisis dengan program AMOS 21

Tabel 9 menunjukkan bahwa Y.1.1 berkontribusi sebesar $78.9 \%$ dengan nilai loading sebesar 0.789 yang berarti indikator tersebut paling dominan dari pada indikator lain. Kedua indikator lain, yaitu $\mathrm{Y}_{1.2}$ dan $\mathrm{X}_{1.3}$ masing-masing berkontribusi pada pengukuran keragaman variabel pembiayaan sebesar $72.4 \%$ dan $54.6 \%$. Kontribusi masing-masing indikator tersebut diukur melalui nilai loading yang masing-masing bernilai 0.724 dan 0.546 .

\section{Uji Kesesuaian Model (Goodness of Fit Test)}

Kegunaan pengujian ini agar dapat mengidentifikasikan apakah model yang sudah jadi sudah layak atau masih tidak layak. Analisis SEM memiliki enam indeks pengujian dalam melakukan penelitian, yaitu chi square, RMSEA, GFI, AFGI, TLI, dan CFI. Keenam indeks pengujian tersebut memiliki kriteria yang dapat membuat suatu model dikatakan layak karena sudah sesuai dengan nilai cut off. Kriteria layak pada uji chi square jika probabilitas chi square $\geq$ level of significant. Kriteria RMSEA dikatakan layak jika nilai RMSEA $\leq$ nilai cut off (0.08) sedangkan keempat uji lainnya dikatakan layak jika nilai goodness of fit $\geq 0.9$.

Tabel 10 Hasil uji kesesuaian model

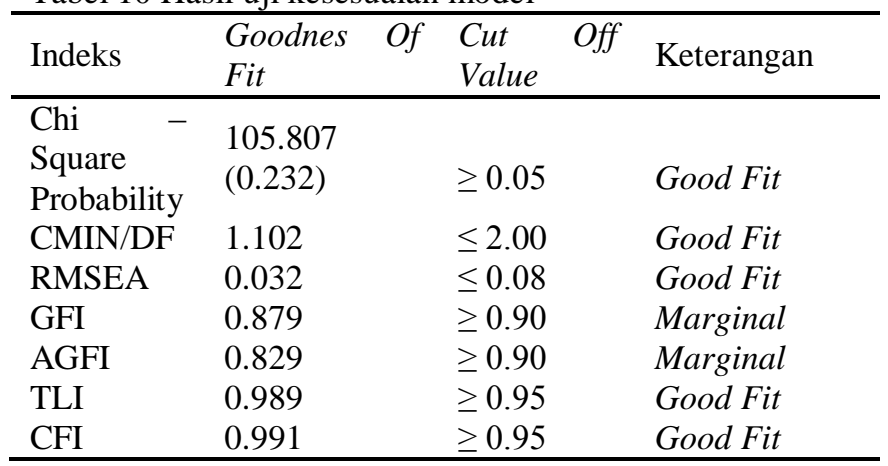

Sumber: Analisis dengan program AMOS 21

Tabel 11 Hasil Uji Kausalitas Model

\begin{tabular}{|c|c|c|c|c|c|c|c|}
\hline & & & Estimate & S.E. & C.R. & $\mathrm{P}$ & Label \\
\hline $\mathrm{F} 4$ & $<---$ & F1 & -.051 & .112 & -.461 & .645 & \\
\hline $\mathrm{F} 4$ & $<---$ & $\mathrm{F} 2$ & .052 & .114 & .462 & .644 & \\
\hline F4 & $<---$ & F3 & .832 & .090 & 9.275 & $* * *$ & \\
\hline $\mathrm{X} 15$ & $<--$ & $\mathrm{F} 1$ & 1.000 & & & & \\
\hline X14 & $<---$ & $\mathrm{F} 1$ & .944 & .094 & 10.048 & $* * *$ & \\
\hline X13 & $<--$ & $\mathrm{F} 1$ & .863 & .091 & 9.533 & $* * *$ & \\
\hline $\mathrm{X} 12$ & $<--$ & $\mathrm{F} 1$ & .833 & .091 & 9.109 & $* * *$ & \\
\hline X11 & $<---$ & F1 & 1.013 & .101 & 10.013 & $* * *$ & \\
\hline X24 & $<--$ & $\mathrm{F} 2$ & 1.000 & & & & \\
\hline $\mathrm{X} 23$ & $<--$ & $\mathrm{F} 2$ & .938 & .096 & 9.821 & $* * *$ & \\
\hline $\mathrm{X} 22$ & $<---$ & $\mathrm{F} 2$ & .882 & .098 & 9.025 & $* * *$ & \\
\hline X21 & $<---$ & $\mathrm{F} 2$ & 1.288 & .104 & 12.343 & $* * *$ & \\
\hline
\end{tabular}


Tabel 11 Lanjutan

\begin{tabular}{llllllll}
\hline & & & Estimate & S.E. & C.R. & P & Label \\
\hline X34 & $<---$ & F3 & 1.000 & & & & \\
X33 & $<---$ & F3 & .726 & .086 & 8.455 & $* * *$ & \\
X32 & $<---$ & F3 & .996 & .088 & 11.279 & $* * *$ & \\
X31 & $<---$ & F3 & 1.050 & .102 & 10.322 & $* * *$ \\
Y11 & $<---$ & F4 & 1.000 & & & & \\
Y12 & $<---$ & F4 & .819 & .109 & 7.517 & $* *$ & \\
Y13 & $<---$ & F4 & .430 & .079 & 5.432 & $* * *$ & \\
\hline
\end{tabular}

Sumber: Analisis Program AMOS 21

\section{Uji Kausalitas}

Uji kausalitas merupakan uji selanjutnya yang dilakukan untuk menguji suatu model hipotesis.

Interpretasi masing-masing koefisien jalur pada Tabel 11 adalah sebagai berikut:

a. Berdasarkan hasil uji kausalitas di atas bahwa hubungan pengetahuan (F1) mempengaruhi preferensi petani terhadap pembiayaan syariah (F4) tidak berpengaruh signifikan dengan koefisien jalur 0.012 C.R -0.461. Probabilitas pada hipotesis pertama menghasilkan nilai 0.645 dan $\geq 0.05$ sehingga tidak berpengaruh langsung pada preferensi pembiayaan syariah. Hasil uji kausalitas pada hipotesis pertama memiliki arti bahwa hipotesis tidak mendukung dan ditolak.

b. Berdasarkan hasil uji kausalitas di atas bahwa hubungan kemudahan (F2) mempengaruhi preferensi petani terhadap pembiayaan syariah (F4) tidak berpengaruh signifikan dengan koefisien jalur 0.014 C.R 0.462. Probabilitas pada hipotesis pertama menghasilkan nilai 0.644 dan $\geq 0.05$ sehingga tidak berpengaruh langsung pada preferensi pembiayaan syariah. Hasil uji kausalitas pada hipotesis kedua memiliki arti bahwa hipotesis tidak mendukung dan ditolak.

c. Berdasarkan hasil uji kausalitas di atas bahwa hubungan kepercayaan (F3) mempengaruhi preferensi petani terhadap pembiayaan syariah (F4) dan berpengaruh signifikan dengan koefisien jalur 0.09 C.R 9.275. Probabilitas pada hipotesis pertama menghasilkan nilai $\leq$ 0.05 sehingga berpengaruh langsung pada preferensi pembiayaan syariah. Hasil uji kausalitas pada hipotesis ketiga memiliki arti bahwa hipotesis mendukung dan ditolak. d. Hubungan setiap indikator variabel laten menunjukkan nilai yang signifikan dimana probabilitas lebih kecil dari 0.05 yang dalam program AMOS 21 dilambangkan dengan tanda bintang. Hasil tersebut memberikan arti bahwa semua indikator sangat baik menjelaskan dan mengukur masing-masing variabel.

\section{Uji Hipotesis}

Berdasarakan interpretasi masing-masing koefisien jalur pada sub bab sebelumnya, Tabel 12 akan menjelaskan dengan ringkas hasil uji ketiga hipotesis.

Tabel 12 Hasil hipotesis

\begin{tabular}{lll}
\hline No. Hipotesis Penelitian & Keterangan \\
\hline
\end{tabular}

Faktor Pengetahuan

1. Berpengaruh Signifikan Ditolak

Pembiayaan Syariah

Faktor Kemudahan

2. Berpengaruh Signifikan

2. Terhadap Minat Menggunakan Ditolak

Pembiayaan Syariah

Faktor Kepercayaan

3. Berpengaruh Signifikan $\quad$ Diterima Pembiayaan Syariah

Sumber: Analisis dengan program AMOS 21

Uji kausalitas menunjukkan bahwa hanya ada satu hipotesis yang diterima, yaitu hipotesis ketiga yang menunjukkan bahwa faktor kepercayaan memiliki pengaruh yang signifikan terhadap minat petani melakukan pembiayaan syariah dengan koefisien jalur positif 0.090 C.R 9.275 serta probabilitas $\leq 0.05$. Sedangkan faktor pengetahuan dan kemudahan tidak berpengaruh signifikan terhadap pembiayaan syariah. 
Berdasarkan hasil penelitian maka peneliti menemukan penguatan terhadap teori yang ada bahwa kepercayaan memang mempengaruhi keputusan seseorang dalam menentukan minat terhadap sesuatu.

Preferensi seseorang terhadap pembiayaan syariah dipengaruhi oleh faktor kepercayaan karena peneliti menyimpulkan dari sebagian besar responden yang didapatkan bahwa faktor kepercayaan merupakan faktor yang dapat langsung mempengaruhi pilihan seseorang terhadap sesuatu. Walaupun seseorang tersebut mempunyai pengetahuan yang matang terhadap sesuatu atau mempunyai presepsi kemudahan yang baik maka belum tentu seseorang tersebut berminat memilih minatnya terhadap sesuatu. Kepercayaan merupakan faktor psikologis seseorang yang menjadikan rasa keyakinan terhadap sesuatu. Dari responden yang ada peneliti menemukan jawaban $43 \%$ responden menjawab sangat percaya akan pembiayaan model syariah, dan hanya $3.75 \%$ saja responden yang menjawab tidak percaya. Ini menunjukkan petani memang membutuhkan pembiayaan dan kondisi yang sesuai dengan usaha pertanian, selain itu kebutuhan spiritual masyarakat juga merupakan hal yang sangat penting terpenuhi karena berkaitan dengan keyakinan agama demi tercapainya ketentraman dan kebahagiaan hidup di dunia. Atas dasar itulah kepercayaan menjadi faktor yang mendorong petani berminat terhadap model pembiayaan syariah.

1. Pengaruh Pengetahuan terhadap Preferensi Petani menggunakan model pembiayaan Syariah

Faktor pengetahuan merupakan faktor pertama yang mempengaruhi seseorang dalam menentukan keputusan atau minat terhadap sesuatu. Minat suka, ingin, tidak suka, dan tidak ingin seseorang tidak dapat ditentukan sebelum seseorang tersebut secara langsung maupun tidak langsung memiliki pengetahuan terhadap sesuatu tersebut yang akan menjadi justifikasi atau alasan seseorang menentukan sebuah pilihan. Peneliti menggunakan faktor pengetahuan untuk melihat preferensi atau minat petani terhadap pembiayaan syariah yang didukung atas dasar pemikiran dan beberapa teori serta studi empirik yang ada.

Hasil pengujian koefisien jalur menunjukkan bahwa variabel pengetahuan berpengaruh tidak signifikan terhadap pembiayaan syariah. Uji kausalitas hipotesis pertama ditolak karena menunjukkan bahwa pengetahuan memiliki pengaruh signifikan terhadap minat petani menggunakan pembiayaan syariah. Berdasarkan temuan di lapangan, peneliti menemukan alasan yang menunjukkan bahwa hasil penelitian menghasilkan pengetahuan tidak berpengaruh terhadap minat petani. Berdasarkan hasil pengamatan di daerah penelitian banyak petani yang masih belum mengetahui tentang pengetahuan terhadap model pembiayaan syariah seperti skema Mudharabah, murabahah atau salam. Peneliti menemukan bahwa walaupun petani mengetahui akan larangan riba atau bunga dan percaya akan aturan Islam, akan tetapi sebagian besar responden belum mengetahui secara mendalam terkait sistem aturan syariah Islam khususnya dalam model pembiayaan ini. Selain itu sikap petani yang masih kaku juga mempengaruhi minat petani terhadap pembiayaan syariah. Kaku yang dimaksud oleh peneliti adalah responden masih sulit untuk menerima sesuatu yang baru dikerenakan kecenderungan sikap yang bertahan terhadap pilihan pertama atau sebelumya. Artinya petani yang sudah terlanjur menjatuhkan pilihannya terhadap sesuatu maka sulit bagi petani untuk memilih pada pilihan lainya, misalkan saja saat seseorang sudah terlanjur percaya kepada bank "A", maka seseorang tersebut tetap bertahan pada pilihan memilih bank "A" walaupun ada tawaran bank lainnya. Jadi pilihan seseorang tergantung siapa yang lebih dulu menjadi pilihan pertama yang kemudian pilihan pertama itulah yang sulit untuk berpindah ke pilihan lainnya.

2. Pengaruh Kemudahan terhadap Preferensi Petani menggunakan model pembiayaan Syariah

Salah satu faktor yang berpengaruh terhadap keputusan seseorang adalah faktor kemudahan dengan presepsi menentukan minat terhadap kesukaan dan keinginan. Atas dasar 
pemikiran beberapa teori dan studi empirik yang ada, peneliti menggunakan faktor kemudahan untuk melihat preferensi petani terhadap pembiayaan syariah. Hasil pengujian koefisien jalur menghasilkan bahwa kemudahan tidak memiliki pengaruh signifikan pada pembiayaan syariah sehingga hipotesis ditolak.

Hasil penelitan menunjukkan faktor kemudahan tidak berpengaruh terhadap penentuan minat petani, peneliti kemudian menemukan alasan yang didasarkan pada temuan di lapangan. Berdasarkan hasil pengamatan di daerah penelitian, banyak petani yang masih belum pernah melakukan transaksi atau merasakan pembiayaan yang berbasis syariah. Selama ini petani memperoleh pembiayaan dalam memenuhi kebutuhan modalnya dari lembaga keuangan konvensional atau rentenir yang tidak berbasis pada aturan syariat Islam. Atas dasar tersebut dan karena petani belum pernah merasakan kemudahan manfaat secara langsung, maka petani tidak menentukan minatnya terhadap pembiayaan syariah, sedangkan pembiayaan yang sifatnya konvensional petani sudah bisa merasakan manfaat secara langsung. Selain daripada itu kembali kepada alasan pada hipotesis pertama temuan di lapangan yang menjelaskan tentang kakunya sikap petani terhadap pilihan terhadap sesuatu, yang menjadi pilihan pertama dan manfaat yang sudah dirasakan itulah yang sering kali seseorang bertahan dalam sebuah pilihan.

3. Pengaruh Kepercayaan terhadap Preferensi Petani menggunakan model pembiayaan Syariah

Salah satu faktor seseorang dalam menentukan keputusan adalah faktor kepercayaan. Dengan timbulnya presepsi kepercayaan akan menjadi pendorong, justifikasi atau alasan seseorang untuk menentukan minat kesukaan dan keinginan terhadap sesuatu. Peneliti menggunakan faktor kepercayaan didasarkan pada pemikiran beberapa teori dan studi empirik yang ada.

Hasil pengujian koefisien jalur menunjukkan bahwa bahwa variabel kepercayaan memiliki pengaruh yang signifikan pada pembiayaan syariah. Uji kausalitas hipotesis pada variabel ini diterima karena terbukti signifikan. Dari hasil pengujian diatas, maka penelitian ini menemukan penguatan terhadap teori yang ada bahwa kepercayaan memang mempengaruhi keputusan seseorang dalam menentukan minat terhadap sesuatu. Preferensi seseorang terhadap pembiayaan syariah dipengaruhi oleh faktor kepercayaan karena peneliti menyimpulkan dari sebagian besar responden didapatkan bahwa faktor kepercayaan merupakan faktor yang dapat langsung mempengaruhi pilihan seseorang terhadap sesuatu. Walaupun seseorang tersebut mempunyai pengetahuan yang matang terhadap sesuatu atau mempunyai presepsi kemudahan yang baik maka belum tentu seseorang tersebut berminat memilih minatnya terhadap sesuatu. Kepercayaan merupakan faktor psikologis seseorang yang menjadikan rasa keyakinan terhadap sesuatu. Peneliti mendapatkan hasil yang menyatakan $43 \%$ dari responden sangat percaya terhadap pembiayaan model syariah dan hanya $3.75 \%$ dari responden tidak percaya terhadap pembiayaan model syariah. Hal ini menunjukkan bahwa petani membutuhkan pembiayaan yang sesuai dengan usaha pertanian serta kebutuhan spiritual masyarakat merupakan hal penting karena berkaitan dengan keyakinan agama demi tercapainya ketentramaan dan kebahagiaan hidup di dunia. Atas dasar itulah kepercayaan menjadi faktor yang mendorong petani berminat terhadap model pembiayaan syariah.

\section{KESIMPULAN DAN SARAN}

Hasil analisa terhadap data yang disebar kepada responden menghasilkan hasil sebagai berikut:

a. Hasil penelitian pada pengujian koefisien jalur tidak dapat membuktikan hipotesis dikarenakan variabel pengetahuan tidak memiliki pengaruh signifikan pada pembiayaan syariah.

b. Hasil pengujian koefisien jalur memperoleh fakta bahwa variabel kemudahan tidak memiliki pengaruh signifikan pada pembiayaan syariah dan tidak bisa membuktikan hipotesis. 
c. Hasil pengujian koefisien jalur menunjukkan bahwa bahwa variabel kepercayaan memiliki pengaruh signifikan pada pembiayaan syariah dan membuktikan bahwa hipotesis dapat dibuktikan.

Saran penulis adalah sebagai berikut:

a. Penelitian menemukan bahwa kepercayaan sangat berpengaruh terhadap preferensi petani memilih pembiayaan syariah. Pengembangan pembiayaan syariah pada lembaga keuangan baik pada level perbankan atau koperasi harus meningkatkan kepercayaan produknya untuk konsumen sehingga pembiayaan tersebut dapat diterima oleh konsumen petani.

b. Penelitian selanjutnya diharapkan dapat melihat peluang terbuka untuk mengembangkan model dalam setting yang berbeda dengan memperluas sampel, lokasi penelitian, dan juga disesuaikan dengan karakteristik responden, misalnya: jenis kelamin, usia responden, status perkawinan, tingkat pendidikan, tingkat penghasilan, serta pengalaman responden sehingga dapat menghasilkan informasi yang lebih luas.

\section{DAFTAR PUSTAKA}

Badan Pusat Statistik. (2015). Kecamatan Wuluhan Dalam Angka 2015. Kabupaten Jember: Badan Pusat Statistik Kabupaten Jember di akses dari https://jemberkab.bps.go.id/.

Badan Pusat Statistik. Kabupaten Jember dalam angka 2012-2015. Kabupaten Jember: Badan Pusat Statistik Kabupaten Jember di akses dari https://jemberkab.bps.go.id/.

Badan Pusat Statistik. Provinsi Jawa Timur 2015.: Badan Pusat Statistik Provinsi Jawa Timur di akses dari https://Jatim.bps.go.id/ Diartho, H. C. (2018). Penentuan Sektor Ekonomi Unggulan di Kabupaten Banyuwangi. Media Trend, 13 (1), 146157.
Dimyati, M. (2009). Analisis SEM dalam Uji Pengaruh Beberapa Variabel Terhadap Loyalitas Kajian Berbasis Riset pada Debitur Kredit Usaha Kecil. Jakarta: Mitra Wacana Media.

Ghozali, I. (2005). Aplikasi Analisis Multivariate dengan Program SEM. Semarang: Badan Penerbit UNDIP Semarang.

Jogiyanto. (2007). Sistem Informasi Keperilakuan. Yogyakarta: ANDI.

Kotler, P. (2000). Manajemen Pemasaran, Jakarta: PT Prenhallindo.

Laili, E. F. \& Diartho, H. C. (2018). Pengembangan Kawasan Pertanian Berbasis Tanaman Pangan di Kecamatan Wuluhan, Kabupaten Jember. Journal of Regional and Rural Development Planning, 2 (3), 209-217.

Marwan, A. (1990). Marketing Cetakan Kedua. Yogyakarta: BPFE Universitas Gadjah Mada.

Muktianto, R. T. \& Diartho, H. C. (2018). Komoditas Tembakau Besuki Na-Oogst dalam Perspektif Pembangunan Berkelanjutan di Kabupaten Jember. Caraka Tani: Journal of Sustainable Agriculture. 33 (2), 115-125.

Sholihin, Mahfud, \& Ratmono, D. (2013). Analisis SEM-PLS dengan WarpsPLS 3.0. Yogyakarta: ANDI.

Wiratama, S., Diartho, H. C., \& Prianto, F. W. (2018). Analisis Pembangunan Wilayah Tertinggal di Provinsi Jawa Timur. Jurnal Ekonomi Bisnis dan Akuntansi, 5 (1), 1620. 